\title{
Ethos and symbolic violence among women of science: An empirical study
}

\section{Corresponding author:}

Andrea Cerroni

andrea.cerroni@unimib.it

\section{Zenia Simonella}

zenia.simonella@unimib.it

\begin{abstract}
While scientific challenges raise relevant debates about the ethics of science, the scientific ethos, shattered by post-Mertonian studies, has not received due attention and further conceptualizations in view of the transition to a knowledge society. However, investigating Italian women scientists, it appears to have survived as a reference for scientists, even if the context has changed. Indeed, the ethos of scientists is no longer conceivable as exclusive, but is instead seen as open and dynamic in the interaction with other symbolic references. Therefore, instead of scientific ethos, it is preferable to speak of scientific habit, including the individual symbolic universe and the social practices linked to the scientific role. In so doing, other habits come into focus and interact. In particular, we investigated the interaction between the scientific habit and the gender habit. We argue for a conflict between two such habits and for the existence of a symbolic violence suffered by women scientists. Lastly, a new dimension of the
\end{abstract}


scientific ethos is defined which is not included in the Mertonian definition: a scientific responsibility among scientists in society. Such a picture could shape a new perspective of re-gendering science in society from the standpoint of women's experience as scientists in the knowledge society.

\section{Keywords}

ethos, gender, scientific habit, gender habit, knowledge society, scientific community, symbolic violence

\section{Résumé in French}

Les défis scientifiques d'aujourd'hui consacrent d'importants débats à l'éthique de la science. Pourtant l'ethos scientifique, brisé par les études post-Merton, n'a reçu ni l'attention qu'il mériterait, ni d'élaborations ultérieures en vue de sa transition dans le cadre de la société de la connaissance. Par l'analyse réalisée sur des femmes qui travaillent dans la recherche scientifique en Italie, l'ethos semble pourtant survivre comme point de repère pour les scientifiques, malgré le changement de contexte. Leur ethos n'est plus imaginable comme caractère exclusif, il est au contraire ouvert et dynamique à l'interaction avec d'autres points de repère symboliques appartenant à l'individu. Plutôt que d'un ethos, il vaut mieux adopter ici le terme d'habit scientifique pour comprendre soit l'univers symbolique individuel soit les attitudes liées au rôle scientifique en interaction avec d'autres points de repère de l'individu. Dans cette enquête, on a examiné l'interaction entre habit scientifique et habit de genre. On a soutenu la thèse de l'existence d'un conflit entre ces deux points de repère de l'individu et l'existence d'une violence symbolique subie par les femmes dans la communauté 
scientifique. Enfin, on a identifié une nouvelle dimension de l'ethos qui n'est pas contenue dans la définition de celui de Merton: la responsabilité du scientifique dans la société contemporaine. La recherche offre de nouvelles pistes pour l'inclusion de la perspective du genre dans la science à partir de l'expérience des femmes scientifiques dans la société de la connaissance.

Mots-clés in French: ethos, genre, habit scientifique, habit de genre, société de la connaissance, communauté scientifique, violence symbolique

The implicit assumption of Robert Merton's theory is that scientists take on their role within an isolated scientific community, putting to one side any other role they may have in life, without considering a series of predispositions and attitudes, a system of values and a continued reference to the circles of recognition (Pizzorno, 2007) that influence any individual's daily life. The flaw in this assumption has led post-Merton sociology of science to heavily criticise Merton's concept and, very often, to ignore the issue of scientists' values.

In this article we have first tried to identify some values and norms that can still be considered specific characteristics of a scientific habit, a set of reference values and practices that correspond for some facets to the ethos identified by Merton (1973).

Ethos in the scientific community is a traditional and much-discussed topic of science studies, but in the present article it is developed in a different context. We have also aimed to highlight the possible conflict with the individual symbolic universe (Berger \& Luckman, 1966). In particular we have investigated the relationship between scientific habit and gender habit, the latter referring to the values and practices that make up the 
identity of gender.

Bearing in mind the classic conceptualisations of Weber (1922) and Durkheim (1924), subsequent studies have led to the general consideration that a value must be seen as an end that the individual feels to be obligatory. At the same time, it is desirable for the whole of society, thus being elevated to a collective good, and it cannot be inferred from practices or behaviours. It is primarily for the last reason that sociological treatises have avoided studying this topic, relegating it to the margins of theory (Sciolla, 2008). However, at least in the case of sociology of science, this has been done in too hurried a manner, although, in recent years, the topic of scientific ethos has been revitalized (e.g. Anderson et al., 2010; Barnes, 2007; Enebakk, 2007; Kuipers, 2010; Radder, 2010.), especially under pressure from the applied sciences (e.g. Meyer \& Sandøe, 2010).

\section{From Mertonian community to knowledge society}

It is not the aim of this paper to outline all the interpretations that have been given to Merton's theories and all the studies that have tried to reconstruct the different aspects of his rich and fertile academic journey (e.g. Abraham, 1983; Cohen, 1990; Cole, 2004; Enebakk, 2007;Kalleberg, 2007; Shapin, 1988; Stehr, 1990; Sztompka, 2007; Turner, 2007; Zuckerman, 1988). But we especially intend to emphasise Merton's theoretical elaborations about norms and values in the scientific community.

Merton describes the entire scientific community as being based on technical and moral norms, which are functional to the ultimate aim of science, that is the increment of certified scientific knowledge (Merton, 1973: 270). Thus, a scientist respects these norms because s/he sees them as useful for generating solid scientific 
knowledge.[1] However, a scientist adheres to them also because they are considered 'right and good' Thus, in this sense, technical norms and moral norms are complementary, but Merton continues to maintain a distinction between them.[2] According to Kalleberg (2007), this distinction continues to be problematical because Merton himself had trouble clarifying it in his works. According to Stehr (1978) the distinction between technical and moral norms is emphasised in this way because Merton is primarily interested in the social aspects of the scientific community (the mores) that are the norms and control systems that guarantee its functioning.

CUDOS (communism, universalism, disinterestedness, organized scepticism), along with the accessory norms (humility, originality and the recognition of priority), allows for the existence of opposing behaviours on the part of scientists. This would include arguing, self-gratifying protests, secrecy due to a fear of being preceded, citing only the data that supports the hypothesis, false accusations of plagiary, etc. (Merton, 1973: 402--403). Notoriously, the origin of such 'deviant' behaviour is, according to Merton, the sociological ambivalence arising from a limited or bad integration of the community, as is further argued by his disciple Mitroff (1974). Even so, this ambivalence is functional to the pursuit of the institutional goal.

Merton's ethos has generated a huge debate, leading to the final distancing (e.g. Barnes \& Dolby, 1970; Bourdieu, 1990; Elias et al. 1982; Mulkay, 1976; Whitley, 1974; Ziman 2000). Today, it is necessary to understand how the values of science could be redefined in the current context of contemporary society (Latour, 1987; Stehr 1994, Unesco 2005, Wynne 2007). What is the ethos of the scientific community in the knowledge society? Is there one single ethos or are there sets of values within the scientific community? [3] A redefinition of the ethos really seems to be necessary if a 
new way of understanding scientific knowledge is appearing (Cerroni, 2006, Erickson, 2005; Gibbons et al., 1994; Latour, 1987; Matthew, 2005; Ziman, 2000). In the knowledge society the borders between the scientific community and the (rest of) society become less definite than in the past: scientist role and, probably, ethos are changing.

\section{Re-gendering science}

If we have to consider the community's increasing dependence on society as a whole, we must also register the expansion of the one by means of the other. Taking into consideration this transformation, we can no longer reduce our analysis solely to science and scientific work, to the traditional logic of the scientific community.

Some post-Merton studies have brought to light the disparities within the scientific community, especially those concerning the inter-relation of the genders (e.g. Bruer et al., 1991; Fox, 1999; Rossiter, 1995), something not unknown to Merton (e.g. Merton, 1973: 154--191). Merton was indeed conscious of the risk that the neutrality, impersonality and detachment adopted by sociological language could lead to overlooking certain issues which, on the contrary, should be important for sociological scientists. This is what Merton (1972) calls sociological euphemisms. Furthermore, Merton (1997) underlined another social dynamic caused by the epicene character of the term 'scientist', specifically the fact that all contributions from women to the progress of science were excluded from scientific memory. Nonetheless, it would seem that he did not fully grasp the problem of the relationship between the scientific ethos in which all scientists purport to recognise themselves --- more clearly defined for us as scientific habit --- and the system of values each individual has as a result of the process of 
gender socialisation, which we have defined as gender habit.

It is very important to define scientific habit and gender habit: habit includes the individual symbolic universe and the mental and practical habitudes linked to the scientific role. So the scientific habit doesn't refer necessarily and exclusively to the set of norms and values interiorized in Mertonian ethos. In regards to gender habit, even if the use of the term 'habit' gives the idea of something that can be put on or taken off at will, it pertains to genders because of the processes of socialisation. Not every habit is exclusive, and therefore it is open and dynamic in its interaction with other habits, leaving room for dissonances and conflicts in the individual life. The choice of the term habit appears to be justified by the fact that it makes it possible to analyse the two universes the individual refers to within the scientific community.

The point we wish to argue now is the possibility that there is a conflict between the scientific habit --- acquired during the socialisation process in the scientific community --- and the gender habit --- acquired by learning and taking on differentiated social roles, building normative expectations and stereotypes of each gender (Connell, 2002; Piccone \& Saraceno, 1996). The objective of the present analysis is to understand how the scientific habit and the gender habit interact. In particular, the outcome of this process for women scientists has been identified in the phenomenon that Bourdieu (1994, 2001) called symbolic violence. In our opinion, this concept highlights the conflict of values tied both to the way in which historically scientific life was constructed and to the way the relationship between the genders has developed within the scientific community.

\section{Methodology}


The above-mentioned work is part of a much larger project on the theme of gender and science, the principle objective of which is to understand two themes: the first is the possibly different contribution that women scientists can make to the scientific endeavour; the second is the contribution that the perspective of gender, particularly within social sciences, has made in raising problematical issues, redefining categories and methods, and reflecting on the epistemological status of the disciplines examined. It is, therefore, a study of how women scientists view these two questions, starting from their personal trajectory within the scientific community.

To study the aspects defined above we have adopted a qualitative technique, specifically: a semi-structured interview. The open questions in the interview are divided into three well-defined areas: the personal journey of the scientists, from their choice of degree course up to the moment of the interview; the contribution that women scientists can make to science in cognitive and organisational terms and in what way gender relationships are articulated within the reference community; aspects of science and the scientific profession.

The semi-structured interview was chosen because it seemed the method best suited to investigate these issues, in particular values and norms of scientists compared to standard research methods, such as questionnaires (e.g. Rositi, 2008). More specifically, the norms identified by means of a qualitative methodology can be expressed directly in the words of the respondents rather than being predefined as possible norms (Braxton, 1986), as has been done with ethnographical and anthropological observations (Latour \& Woolgar, 1986), biographical studies (Kanigel, 1986) and focus groups (Anderson et al., 2010). A total of forty Italian women scientists were interviewed for one hour on average: they work in Italian research institutions 
(universities and public institutions), in the fields of biosciences, [4] physics,[5] economics and sociology; have different levels of seniority; and belong to different generations. In the present study, we have chosen to focus only on the fields of biosciences and physics because of the number of exchanges, disciplinary intersections, working collaborations and similarities in scientific careers.[6] Economics and sociology call for a separate scientific analysis.

It should be noted that the problem we have posed above, that is the possibility of a conflict between scientific habit and gender habit and its outcomes, is not a research hypothesis, but already one of the results that has emerged from the interviews carried out with women scientists in the context of this project.

\section{Symbolic violence in the scientific community}

The concept of symbolic violence was introduced by Pierre Bourdieu to explain the relationship between the dominator and the dominated by means of a form of violence that he defined as soft and invisible (Bourdieu, 2001).

Symbolic violence is based on the idea of dominance without discipline, that is the dominated have internalised and inscribed in their body the disposition to submission to a social order that renders it both spontaneous and extorted (Bourdieu, 2001: 38). In fact, symbolic violence is the adherence by the dominated to thought patterns due to the incorporation of dominance. So the dominated person is in every sense an accomplice of the dominator. However, Bourdieu distances himself from a certain philosophy that presupposes an enfranchisement of the dominated by the relationship of dominance the moment they become conscious of their own state. Starting from Favret-Saada's theory (1987) and particularly that of Mathieu (1991), the 
French sociologist argues that symbolic violence is based on a limitation of the possibilities of thought that the dominant imposes on the oppressed. Only a change in the conditions producing such a disposition can break the domination.

In our opinion, the scientific community has a cluster of reference values to which scientists show some allegiance. It is necessary to recognise its existence, even if it is not necessary to attribute to it an exclusive and directive power over behaviour, as would be the case according to Merton's ethos. Then, following Merton (1997), we highlighted the precise connotation of gender, with reference to the male gender, to be interpreted as the dominant gender. If, therefore, belonging to a gender in the scientific community may not be a problem for men of science, it can become one, on the other hand, for women scientists. The creation of a scientific habit can enter into conflict with the gender habit and generate forms of symbolic violence on behaviour, the representation of situations and the formulation of ideal ends and orientations.

First of all, symbolic violence manifests itself at the moment when women scientists, during their interviews, express opinions and apply thought patterns that 'ratify the domination', thus revealing their implicit acceptance of their subordination.

Women tend not to be very understanding, they tend to be more rigid towards women than men do... They are more ready to point out the error of a female colleague: this happens with men, too, but men with men, in some way, form a team; women find it more difficult to form a team. (A nuclear physicist)

On the one hand there is more solidarity among women, but then we say that we would need a few men because women are somewhat catty at times 
(laughs), we become little witches when we shouldn't! (A neuropsychologist)

For example, the first thing that comes to mind is always the aspect that may devalue the woman, even among women themselves! And it happens much more with women. (A string physicist)

When an attractive woman has a good career, the first comment that is made is that she used her looks to further her career and I think this is very wrong, especially when it comes from other women. (A nutritional physicist)

Making negative or denigrating judgements of other women is, according to Bourdieu (2001: 35), an example of how the relationship of dominance is perpetuated by the dominated themselves. Whether the judgement expressed has an empirical basis or not is of little importance: symbolic violence emerges both from a subjective point of view, which concerns the apparatus of categories used for expressing judgements, and from an objective point of view, one tied to behaviours and attitudes brought into play by the individuals and subjected to judgement.

Another aspect of symbolic violence is socially imposed agoraphobia (Bourdieu, 2001: 39). This type of symbolic violence is activated when external limitations on liberty are eliminated, and those who previously did not hold a certain right are now free to exercise it. Facing up to the possibility of inclusion, the subject activates a form of self-exclusion. This is in fact what we noted in our interviewees:

Often, women don't compete for positions of command, which they view 
more as a service to the scientific community than as an opportunity to advance their career. (A particle physicist)

An effect that still exists, but less so, manifests itself towards the end of a career, and it concerns reaching positions of power. The difference still exists. Positions of power, I mean let's make them directors, presidents, nationally responsible for some area... I couldn't say whether the difference is due to the fact that those who decide... I mean...the choices are made by election or coopted, thus with still a masculine preference or if it is an effect that leads to women putting themselves forward less for positions of this type. Probably it's both, the second certainly exists. (A particle physicist)

It's much more likely that they will be papers done in collaboration, but at times there are papers with a single signature... there, I can't think of any paper with a single female signature. (A string physicist)

This form of socially imposed agoraphobia can survive long after the abolition of the more visible prohibitions, leading, for example, to women not competing for positions of authority. According to Bourdieu (2001: 39), these examples are the lasting traces of masculine domination impressed in the body. The way the dominated read and interpret the world is strictly tied to the domination, perpetuating the very form of symbolic violence that they are victims of. Symbolic violence can be revealed by forms of bodily emotions, passions, more or less visible feelings, by means of which the body manifests its reluctance with respect to the limitations imposed by social structures. One 
passes from the perception of unease to manifestations of various degrees of anger.

First of all, I found some texts that I liked and developed a passion for the theme (women and science), but not because I thought there was discrimination, but a certain unease, yes... because, however, I had not had any models, I was somewhat an orphan. And also in the group where I worked they were all men, I felt a certain unease also due to their way of joking, of speaking. (A material physicist)

I don't know if it has been an obstacle for me, it's certainly true that I felt like a fish out of water. Quantifying this unease in terms of a specific activity... in an active attempt to stop me having a career I don't know... also, also, certainly, in a certain way yes, let's call it a strong uneasiness, particularly at the beginning (laughs) because I came from a normal school, where the population was normally represented, men and women! Instead I ended up in a place where there weren't any [women]! It was quite difficult. (A neurobiologist)

I am an insecure person, a bit this too, but this is more typical of women, being less assertive, less... so I often had to fight hard to impose myself, so while I went down this road, repressed anger, to try to impose myself... maybe even slightly hysterically (laughs). (A string physicist)

Yes, I suffer discrimination. But I would prefer to illustrate the situation that is common to all women rather than talk specifically about myself. It is a 
common experience of many women involved in research activities that, until just a few years ago, speaking of discrimination against female researchers created unease and disbelief: in fact, it is difficult for people doing research to admit that there is discrimination in science itself! (A particle physicist)

Given the well-known horizontal and vertical segregation, in the labour market as in the scientific community, the apex of symbolic violence is the denial of a different treatment generally given to men and women:

No, I occasionally noticed that I was the only woman on the faculty, on the commission in Rome, just as in the Presidency of the Commission, I noticed it but... (giggles) it wasn't... It was neither for, nor against... like I never received anything in terms of quotas, just to be clear. (A biologist)

As far as I am concerned, I have not observed any discrimination (pause). I don't think that it is true that it is different for men and women. ( $A$ medical physicist)

I don't think that in my career I have ever had advantages or disadvantages because I am a woman, and I am not very sensitive to the problem of gender, in the sense that I don't think it should exist. (A biologist)

A generational effect can also be identified in these cases. The scientists quoted above belong to a generation of women who have experienced the scientific community 
as an almost totally male universe (especially in the apical positions). This has led them to sometimes make personal sacrifices to reach positions of importance within the community. In particular, the first quote is from a woman occupying a position of considerable authority, who during the interview never spoke of her experience as a woman within the scientific community. This is true also of the second quote. Specifically, both interviews have in common a prevalence of affirmations about science and very little space given to personal experiences. The third quote could also be included here, coming from a biologist who was opposed to a meeting so it was not possible to interview her. The denial of a possibly different treatment of men and women within the scientific community is the trace left by one of the forms of symbolic violence that we wish to highlight. It is in this case an adherence of women to a male model as the result of a long process of adaptation inside the scientific community. We call this attitude homologation. But, women scientists can also adhere to a certain female model, using 'charm and seduction' as instruments for accessing power. We call this attitude differentiation.

In our view, these are two types of symbolic violence that are not exercised with manifest prescription of a certain model, but they represent two ways in which women align themselves with a certain form of domination. These two attitudes reveal a contrast between what we call gender habit and scientific habit: indeed the interviews are characterised by a form of mental division between being a scientist and being a woman

The two forms of symbolic violence are reported by interviewees as two models of adaptation to the scientific community. However, perfectly coherently with the construction of an image of Homo scientificus with no gender, no biography, no 
history,[7] women scientists are influenced by a social current that is difficult and sometimes painful to resist and that pushes them towards two havens: homologating to the dominating gender stereotype (at times becoming almost caricatures) rather than differentiating from it by adopting the stereotype of the dominated gender.

Specifically, the homologation distances itself from that type of gender socialisation that led women to be viewed as objects by others; they adapt to the male model starting from their external appearance, therefore renouncing, in particular, any clothing identifiable with a female model:

First of all giving up clothes (laughs). Look at me! I gave up wearing skirts because I was looked at in a way that bothered me... I felt I was losing credibility. (A string physicist)

The process of adaptation then becomes a daily chore, performed in order to survive within the scientific community:

It is absolutely not nice being few of us and if you want to survive, especially because there are few of us, and specifically because we are in a predominantly male environment, we have to adapt and to compromise with the manner in which men do science. (A string physicist)

Today, to get on, you absolutely have to bare your teeth and claws, and then, obviously, one adopts all the male stereotypes! (A string physicist) 
In the next quote, the female scientist clearly highlights how adhesion to the male model makes the woman look 'awkward', acting in a way that is not her own.

Even if the gender differences are not perceived, they are experienced as obstacles because they force an adaptation to the male model. This is a great limitation, because women are not good at being men, women must be women, and they mustn't shirk historically male roles, therefore taking decisions, and even being capable of difficult decisions. But I think they must do it remembering their cultural history, maybe even their different biological story, there are different ways. Knowing them, discussing them, facing up to them, sharing duties, I think are good ways; imposing male models is not a good way, and men are better at it than we are because it is their own way. I don't know how to express this, because then one becomes awkward... (A nutritional physicist)

According to Bourdieu (2001: 38), these 'bodily emotions' manifest the suffered adherence and complicity of the dominated in the domination relationship.

Women display various forms of adaptation and survival techniques in the scientific community, and these come out in different ways in the stories they tell. One example is the constant attempts to gain credibility within the work groups when women take on a role of responsibility. In this case there is no homologation, but an attempt to adapt to the requirements of the new role.

The problems that I have had to face most frequently have been in the 
relationships with other people when doing my job, in as much as a situation arose, that I couldn't say arose because I am a woman or because I have always worked with a professor who was quite famous abroad, and when I put myself forward to replace him because I was starting to run the laboratory, I ran into some resistance. But, I can't say if this resistance was due to me being a woman or to them being used to the other person. So at a certain point I decided that in order to be heard... then here is the third problem that there is obviously a considerable age difference and so the international people I had to deal with were closer to his age than to mine... so I decided autonomously to follow a managerial coaching course to be enable to impose my new role as boss and to manage relationships. (A biologist)

When it comes down to it, also for women scientists, maternity is a problem in their career path. They try not to interrupt their research activity during or after their pregnancy and to ensure that not the slightest interruption appears in their CV. An important aspect that highlights the conflict between the role of scientist and maternity is clearly outlined by the words of this researcher:

Certainly a gender difference has intervened that is physiological, which is maternity, because here it is nature that determines a major difference. What I can say is that I have been extremely determined. To level the playing field with those who have no children and those who are not women, you have to give more, that's the truth and there is nothing one can do about it. It is nature itself that imposes it. This is one point. Then the difficulty that I encountered, that I 
found is physiological, is that the mind of a mother, especially in the first year, is strongly diverted towards parenthood. The attention, memory, efficiency that one needs to do a job like that of a scientist, therefore, hmm... it is a job requiring great precision, a good memory, so I have to say that a great difficulty I encountered was this one, that is, in inverted commas, opposing myself to the physiology of my mind at least in the early days. (A biophysicist)

This biophysicist is evidently talking about difficulty on a physiological level. It can, however, be used as a metaphor to represent this state of schism and deep ambivalence that women scientists live within the scientific community.

Finally, the following quotation summarizes the two forms of symbolic violence:

The women around me, in theoretical physics, had sort of divided themselves into two categories. On one side, among whom I saw myself, were those who had partially given up being women, a subconscious reaction, deleting anything that could be part of their femininity in order to try to find credibility as a person. There is then a group of women who reacted in the opposite manner... (pause) understanding that femininity could be an alternative route (laughs), and they exploited it, and I have to say that there are, there are some... they work in collaboration, without an important role in the collaboration, trying to impress the men with their femininity. So in some way to charm the influential people in order to absorb their influence through them, that's choosing to be... hmm... the woman close to the important person rather than trying to be themselves on their own journey. They try to influence important people by means of feminine 
charm, conserving and exalting their femininity. (A string physicist)

Let's say that there are men who encourage this form of adaptation...female colleagues have spoken to me about sexual harassment, there have been some moments in the career of my female colleagues when they have deviated from this kind of behaviour, and this is not acceptable today! It's a mine field! (A nutritional physicist)

The first quote clearly highlights both forms of symbolic violence. In particular, differentiation implies a certain level of exchange, as Bourdieu analysed so well, and it is identified explicitly as an instrument for reaching certain objectives, where "charm and seduction' become indirect means of accessing power. According to the second quotation, differentiation is implicitly encouraged by men. An explicit encouragement can go on to become sexual harassment at work, but this is no longer a case of symbolic violence.

To sum up, the interviews generally reveal a certain awareness of the two forms of symbolic violence. The words of the scientists reveal different forms of unease, but, at the same time, an attempt at enfranchisement and a search for a balance between their gender habit and the scientific habit they wear in the scientific community, in which they share a series of norms and values that create the scientific community.

\section{Scientific ethos in the knowledge society}

What emerges from the interviews about the scientific habit? Can we speak of norms and counter-norms within the scientific community, following Merton and Mitroff? Is 
the ethos changing in the knowledge society? Some of the norms and counter-norms studied by Merton (1973) and Mitroff (1974) emerge from the interviews, and the implicit or explicit adherence to them depends on an evaluation of the context on behalf of the scientist. Women scientists were not asked to express themselves on Mertonian norms and anti-norms; nonetheless, they referred to them spontaneously.

\begin{tabular}{|c|c|}
\hline Norms & Counter-norms \\
\hline $\begin{array}{l}\text { Universalism/Emotional neutrality } \\
\text { 'This is the most important thing, the } \\
\text { experiment and the interpretation must be } \\
\text { carried out objectively, in a detached and } \\
\text { honest manner.' }\end{array}$ & $\begin{array}{l}\text { Emotional commitment } \\
\text { 'A slight detachment is perhaps necessary, I } \\
\text { think, but one must also feel involved because } \\
\text { one is doing it out of passion.' }\end{array}$ \\
\hline $\begin{array}{l}\text { Communism } \\
\text { 'The fact is that anyway science represents a } \\
\text { universal good.' }\end{array}$ & $\begin{array}{l}\text { Solitariness/Secrecy } \\
\text { 'I'd think hard about making public something } \\
\text { that I could imagine might be used against the } \\
\text { aim of science, which is bettering man's } \\
\text { existence. If I find something that could kill I } \\
\text { probably would avoid making it known, } \\
\text { because I'm afraid an improper use may be } \\
\text { made of it. This is implicit in the concept of } \\
\text { objectivity and ethics in the divulgation of } \\
\text { data.' }\end{array}$ \\
\hline
\end{tabular}




\begin{tabular}{|l|l|}
\hline Disinterestedness & $\begin{array}{l}\text { Interest } \\
\text { 'In science it is possible to exercise } \\
\text { considerable intellectual freedom, we are not } \\
\text { conditioned by anything other than curiosity, } \\
\text { the desire to know and to experiment.' you are the one doing that } \\
\text { experiment, it's pointless denying it, if we are } \\
\text { here it's also because of this! Then the social } \\
\text { component of science comes into play, so I'm } \\
\text { working with public money... just being here } \\
\text { 'The fact of doubting one's own ideas, } \\
\text { criticising them.' }\end{array}$ \\
$\begin{array}{l}\text { Organized scepticism } \\
\text { Organized dogmatism } \\
\text { 'Doubt is the best thing that can happen! You } \\
\text { see something completely differently to how } \\
\text { others have seen it. Is it true or not? Obviously, } \\
\text { you don't let something go if you see it } \\
\text { differently to other people. So, you add } \\
\text { controls, you approach the experiment using } \\
\text { different techniques. You're afraid... Then, } \\
\text { when you realise that you have done everything } \\
\text { you could do, you write up the work and see } \\
\text { what critics say about it ... I'm ready to change } \\
\text { my mind ... but not to give up immediately.' }\end{array}$ \\
\hline
\end{tabular}




\section{Humility}

'However, all scientists know that to go forward they must talk to each other, they

must... I'm not saying be humble... yes,

humble because they doubt themselves... if an

idea collapses it's not the end of the world...

indeed, if they can go on it's better for their

work.'

Even if we can affirm that these statements reveal the presence of CUDOS and of the relative counter-norms (Mitroff, 1974), nonetheless, following up on Mulkay's criticism (1976), we cannot say that such norms are effectively institutionalised. In other words, it is not clear whether such norms lead to what Merton called a certified knowledge. After all, if there were an institutionalisation, the distribution of prizes and rewards would be positively tied to conformity with these norms, while according to Mulkay (1976), this does not happen. Indeed, the reward system is based on the violation of the principle of universalism, as the experiences of the scientists interviewed demonstrate.

However, a number of statements highlight that scientists share those norms and conform themselves to a certain image that the scientific community wishes to transmit to the outside world. We have to recognise that a sociologist, when interviewing a biologist or a physicist, is an outsider (Merton, 1972) to that scientific sub-community. In fact, the image of scientists that emerges from the interviews is in line with a certain social stereotype of the scientist. 
In any case, the regularity of the affirmations is the symptom of the presence of a scientific habit, that is, of a series of reference values that represent the glue among scientists: doubt and criticism, honesty in carrying out one's work and the rigour of the scientific methodology adopted are values that were repeatedly cited by the interviewees. Furthermore, scientists are aware that the scientific community cannot be seen as an autonomous universe, as previewed by Merton (1973). The scientific community becomes one of the actors within the knowledge society, questioning even its partial autonomy as Bourdieu (1994) thought. Therefore, in the knowledge society, while everyone interacts ever more strongly with each other, everyone adopts practices, values, organizational structures and professional figures concerning the other actors and changes internally. This process can generate different outcomes, like the asymmetrical convergence between industry and academy, as theorized by Kleinman and Vallas (2001): although codes and practices circulate in both directions industry ultimately appears to have an upper hand in this process.

Reading through the interviews, we find evidence for an ethic of responsibility concerning the relationship between means and ends and the consequences of one's own actions: the responsibility of doing one's job honestly and correctly, of being transparent and conscientious in the use of public funds, of being open within one's community, of communicating the research results to citizens and allowing them to partake in the scientific work, making them aware of the risks and consequences their discoveries may generate. So such responsibility goes well beyond the classical scientific work and the scientist comes out from the scientific community, becoming a knowledge citizen: on the one hand, participating to the societal decision making with his/her expertise; on the other hand, facilitating the non expert participation and 
promoting the development of knowledge as a global public good. The scientific community can be viewed in parallel to enterprises and collective subjects that adhere in their charter of values to a corporate social responsibility: starting with a public statement of intentions, they implement sustainable policies, both inwardly towards the organization (typically towards the employees) and outwardly (towards the general community).Likewise, the scientific community is called upon to take on responsibility towards all stakeholders and no longer just the shareholders (i.e. the scientists).

Scientists find themselves caught between a scientific community that is changing its role and values in the knowledge society and the ethos inherited from the autonomous scientific community Merton spoke about (1973). What seems to emerge is a habit that not only forces the community to achieve certified knowledge, but also points at a knowledge citizenship. Scientists experience such push even if it fuels internal conflicts, disorientation and new external problems that are not easily solved. Thus, our women scientists remain tied to the constitutive values of science as represented by Merton's ethos, but they feel them changing:

It is a great responsibility, but it is somewhat ignored by us, in the sense that specially when we are in a phase of post-academic science, in which there are no more guarantees for research, guarantees of being within the academy... we have to look for funds, we have to deal with industrial research, use the same methods, the same language. We would often like to have contact with people who do research inside the industries... in this case anyone doing research becomes, those who do research, look for funds, try to convince people that their research and subject are the best, half way between propaganda and research, and it is not easy to maintain an ethical stance. (A material physicist) 
I would say that those values have been shattered, in the sense that finding your way here and there is quite a job, in the moment in which... in the next EU framework programme the fundamental point will be innovation and innovation and competitiveness and less and less money will be dedicated to fundamental research. This says a lot about the background of values, scientists are becoming... or people are trying to push them to become organizers of applicable knowledge. The problem is that once ideas are finished so are the applications. If scientists are not given the chance to 'waste time' after a problem that has no immediate application, innovation collapses and I think even quite quickly. I hope some thought will be given to this. As things are today, people who work in science are very confined to the applicability of what they are doing and this makes us less free. (A nutritional physicist)

In fact, the values that 'have been shattered' make way for other values, tied to market forces and knowledge citizenship.

Even in competition with others, Merton's ethos still seems to be a reference for the interpretation of these changes.

\section{Conclusions}

In this article, we have described symbolic violence to women scientists as an example of conflict between two clusters of reference values: gender habit and scientific habit.

However, symbolic violence is not a phenomenon that regards only the scientific community; here it takes on a particular symbolic charge. It manifests itself in that 
human activity, science, which exerts a powerful thrust towards freedom, even if, right from the start and for a long time, the scientific community was a world without women (Noble, 1992).

What can the phenomenon of symbolic violence say to the ethos of science? First of all, symbolic violence in the scientific community finds fertile ground exactly in the systematic violation of the Mertonian universalism that should consider equally all the independent sources of the characteristics of each subject. In fact, this violence, based on the incorporation of the dominance in the dominated, as we argued, can be amplified in presence of gender inequalities, perpetuating those dispositions that generate the symbolic violence. Thus, primarily, the case of symbolic violence vindicates a renewed centrality of the norm of universality, starting with the consideration of gender differences in the scientific community. This is not in contradiction with the norm of universality: indeed, equality-difference couple is a thema at the core of the literature studying differences (e.g. "the dilemma of difference" by Martha Minow, 1985).

Secondly, criticisms of Homo scientificus can take into account the affirmation of a culture of responsibility regarding the type of science generated, the subjects that produce it, the direction in which it develops, the awareness of the presence or not of interests and ideologies, the structure of the scientific field and what is at stake. This is not mere accountability, having to refer to third parties about the resources used and results achieved (bureaucratic ethos); it refers more specifically to a responsibility in a wider general interest that transcends the scientific community itself, extending to personal interests and roles (civic ethos). In this ethic of responsibility, we see the reflective practice of the scientific community on itself. This is the way we could read 
post-war pacifist movements, the diffusion of ecological themes and the creation of international forums of scientists involved in the democratic aspect of global society.

Lastly, the experiences of the women scientists interviewed seem to point to a new and alternative way from the two "disciplined"[8] as Bourdieu would say: homologation and differentiation. This way starts precisely with distancing oneself from the 'Legend of Science' (Kitcher, 1993), and thus inaugurating the prospect of regendering science in society.

\section{Notes}

1 As Lynch highlighted (1997:60), Merton is aware of the external pressures on science, however does not ask himself what social conditions generate that knowledge, but instead what institutional conditions are necessary for producing it.

2 In contrast to Merton, various authors underline the importance of history and the interdependence between technical (or cognitive) norms and moral (or social) norms (Bourdieu, 1990; Knorr Cetina, 1977; Rip, 1982: 233).

3 Elias (1982) maintains that each discipline, each department, differs in terms of the beliefs and values founding the knowledge they produce.

4 One working on bio-physics, three on biotechnologies, three on neurosciences, three on biological chemistry.

5 Four scientists working on string physics, one on materials physics, one on the physics of the atmosphere, four on particle physics, one on medical physics,.

6 For the present analysis it is not significant to contextualise the empirical material with respect to the specific scientific fields and focus on the different epistemic 
cultures (Knorr Cetina, 1999).

7 The criticism of neutrality has been animated by many feminist researchers: e.g. Keller (1985), Harding (1986), Rose (1994). Homo scientificus, without gender, history and any biography, recalls the criticism made by many feminist economists of Homo economicus, who describe him as an ageless man with no childhood, fully formed, with already stated preferences, with no responsibility towards anyone except himself (Feber \& Nelson, 1993). Feminist economists have not been the only ones to attack Homo economicus; there are also the criticisms since Alfred Marshall (1890).

8 "Disciplined" refers to the peculiarity of the symbolic violence that is a submission extorted to the dominated without an explicit order, but that has intrinsically a call to order that the dominated recognise and accept. In this sense, the two way - homologation and differentiation - are "disciplined": i.e. women are forced to conform to a behavioural discipline and the scientific discipline results gendered.

\section{References}

Abraham GA (1983). Misunderstandings the Merton Thesis. A Boundary Dispute between History and Sociology. Isis, 74 (3), pp. 368-387.

Anderson MS, Ronning EA, De Vries R, et al. (2010) Extending the Mertonian norms: Scientists's subscription to norms of research. The Journal of Higher Education 81(3): 366--393.

Barnes SB (2007) Catching up with Robert Merton. Journal of Classical Sociology

7(2): 179-192. 
Barnes SB, Dolby RGA (1970) The scientific ethos: A deviant viewpoint. European Journal of Sociology (11): 3--25.

Ben-David J (1974) The Scientist's Role in Society. Chicago, IL: University of Chicago Press.

Berger PL, Luckmann T (1966) The Social Construction of Reality. A treatise in the sociology of knowledge. New York, NY: Anchor Books.

Bourdieu P (1990) Animadversiones in Merton. In: Clark J, Modgil C, Modgil S (eds.)

Robert K. Merton. Consesus and controversy. London: Falmer Press, 297--301.

Bourdieu P (1994) Raisons Pratiques. Sur la théorie de l'action. Paris: Seuil.

Bourdieu P (2001) Masculine Domination. Stanford, CA: Stanford University Press.

Braxton JM (1986) The normative structure of science: Social control in the academic profession. In: Smart CJ (ed.) Higher Education: Handbook of theory and research. New York, NY: Agathon Press, II: 309--317.

Bruer J, Cole J, Zuckermann H (1991) The Outer Circle. New York, NY: Norton.

Cerroni A (2006) Scienza e Società della Conoscenza. Turin: Utet.

Cohen IB (1990) Some documentary reflections of the dissemination and reception of the 'Merton Thesis'. In: Clark J, Modgil C, Modgil S (eds) Robert K. Merton. Consesus and controversy. London: Falmer Press, 307--348.

Cole J (2004) Robert K. Merton. Scientometrics 60(1): 37--40.

Connell RW (2002) Gender. Cambridge: Polity Press.

Durkheim E (1924) Sociologie et Philosophie. Paris: Alcan.

Elias N (1982) Scientific Establishments. In Elias N, Matins H, Whitley R (eds) Scientific Establishments and Hierarchies. Sociology of the sciences. Dordrecht: 
Reidel, 3--69.

Enebakk V (2007) The three Merton theses. Journal of Classical Sociology 7(2): 221-238.

Favret-Saada J (1987) L'arraisonnement des femmes. Les Temps Modernes, 487, 137-150.

Feber MA, Nelson JA (1993) Beyond Economic Man. Chicago, IL: University of Chicago Press.

Fox MF (1999) Gender, hierarchy, and science. In: Chafez J (ed.) Handbook of The Sociology of Gender. New York, NY: Kluwer.

Gibbons M, Limoges C, Nowotny H, et al. (1994) The New Production of Knowledge: The dynamics of science and research in contemporary societies. London: Sage. Harding S (1986) The Science Question in Feminism. Ithaca, NY: Cornell University Press.

Kalleberg R (2007) A Reconstruction of The Ethos of Science. Journal of Classical Sociology, 7(2): 137-160.

Kanigel R (1986) Apprentice to Genius: The making of a scientific dynasty. New York, NY: MacMillan.

Keller Fox E (1985) Gender and Science. New Haven: Yale University Press.

Kitcher P (1993) The Advancement of Science. Science without legend, objectivity without illusion. New York, NY: Oxford University Press.

Kleinman DL, Vallas SP (2001) Science, Capitalism and The Rise of the "Knowledge Worker": The Changing Structure of Knowledge Production in the United States. Theory and Society, 30(4), 451-492. 
Knorr-Cetina K (1977) Producing and reproducing knowledge: Descriptive or constructive? Toward a model of research production. Social Science Information 16(6): 669--696.

Knorr-Cetina K (1999) Epistemic Cultures: How the sciences make knowledge. Cambridge, MA: Harvard University Press.

Kuipers TAF (2010) The grey area for incorruptible scientific research. In: Suarez M, Dorato M, Rédei M (eds) EPSA Epistemology and Methodology of Science. Dordrecht Heidelberg London New York: Springer, 149--164.

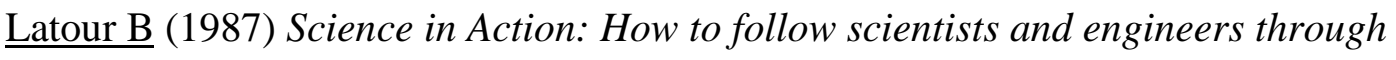
society. Cambridge, MA: Harvard University Press.

Latour B, Woolgar S (1986) Laboratory Life. The construction of scientific facts. Princeton NJ: Princeton University Press

Lynch M (1997) Scientific Practice and Ordinary Action. New York, NY: Cambridge University Press.

Marshall A (1890) Principles of Economics. London: Macmillan.

Mathieu NC (1991) L'Anatomie Politique: Catégorisation et idéologies de sexe. Paris: Coté-Femmes.

Matthew D (2005) Science in Society. Basingstoke: Palgrave.

Meyer G, Sandøe P (2010) Going public: Good scientific conduct. Science and Engineering Ethics. Published on line first.

Merton RK (1972) Insiders and outsiders: a chapter in the sociology of knowledge. American Journal of Sociology 78(1): 9--47.

Merton RK (1973) The Sociology of Science: Theoretical and empirical investigations. 
Chicago, Il: University of Chicago Press.

Merton RK (1997) De-gendering 'Man of Science': The genesis and epicene character of the word Scientist. In: Erikson K (ed.) Sociological Visions. New York, NY: Rowman \& Littlefield, 225--254.

Minow M (1985) Learning to Live with the Dilemma of Difference: Bilingual and Special Education. Law and Contemporary Problems, 41(2), 157-211.

Mitroff I (1974) Norms and counter-norms in a select group of the Apollo moon scientists: Case study of the ambivalence of scientists. American Sociological Review 39(4): 579--595.

Mulkay MJ (1976) Norms and ideology in science. Sociology of Scientific Information 15(4/5): 637--656.

Noble D (1992) A World Without Women. The Christian clerical culture of Western science. New York, NY: Knopf.

Piccone S, Saraceno C (1996) Genere. La costruzione sociale del femminile e del maschile. Bologna: Il Mulino.

Pizzorno A (2007) Il Velo della Diversità. Studi su razionalità e riconoscimento. Milano: Feltrinelli.

Radder H (2010) A deflationary, Neo-Mertonian critique of academic patenting. In: Suarez M, Dorato M, Rédei M (eds) EPSA Epistemology and Methodology of Science. Dordrecht Heidelberg London New York: Springer, 221--232.

Rip A (1982) The development of restrictedness in the sciences. In: Elias N, Matins H, Whitley R (eds) Scientific Establishments and Hierarchies. Sociology of the sciences. Dordrecht: Reidel, 219--238.

Rose H (1994) Love, Power and Knowledge. Cambridge: Polity Press. 
Rositi F (2008) Sulla distinzione fra scopi e valori. Rassegna Italiana di Sociologia 49(1): 5--38

Rossiter M (1993) The Matthew Matilda effect in science. Social Studies of Science 23(2): 325--341.

Rossiter M (1995) Women Scientists in America: Before affirmative action 1940--1972.

Baltimore, MD: Johns Hopkins University Press.

Sciolla L (2008) La forza dei valori. Rassegna Italiana di Sociologia 49(1): 89--115.

Shapin S (1988) Understanding the Merton thesis. Isis 79(4): 594--605.

Stehr N (1978) The ethos of science revisited. Social and cognitive norms. Sociological Inquiry 48(3-4): 172--196.

Stehr N (1990) Robert K. Merton's sociology of science. In: Clark J, Modgil C, Modgil S (eds) Robert K. Merton. Consesus and Controversy. London: Falmer Press, $371--383$.

Stehr N (1994) Knowledge Societies. London: Sage.

Sztompka P (2007) Trust in science. Journal of Classical Sociology 7(2): 211--220.

Turner S (2007) Merton's norms in political and intellectual context. Journal of Classical Sociology 7(2): 161--178.

Unesco (2005) Towards Knowledge Societies. Paris: Unesco.

Weber M (1922) Wirtscaft und Gesellscaft. Tubingen: Mohr.

Whitley R (1974) Social Process of Scientific Development. London: Routledge.

Wynne B (2007) Taking European Knowledge Society Seriously. Brussels: European Commission. 
Ziman J (2000) Real Science: What it is, and what it means. Cambridge: Cambridge University Press.

Zuckerman H (1988) The sociology of science. In: Smelser NJ (ed.) Handbook of Sociology. Beverly Hills, CA: Sage Publications, 511--573.

\section{Author biographies}

Andrea Cerroni is a Senior Researcher in the Center MaCSIS, Department of Sociology and Social Research of the University of Milan-Bicocca

8, via Bicocca degli Arcimboldi, 20126 Milan (Italy).

Research topics: sociology and communication of science; knowledge society.

Zenia Simonella is a PhD candidate in Sociology at the University of Milan-Bicocca and Istituto Italiano di Scienze Umane (SUM).

Istituto Italiano di Scienze Umane (SUM) - Piazza Strozzi, 50123, Florence (Italy) University of Milano-Bicocca - 8, via Bicocca degli Arcimboldi, 20126 Milan (Italy)

Thesis topic: gender and science. My phd thesis is a sociological study of the scientific community through the gender lens. 
